\title{
PERAN ADVERSITY QUOTIENT MEMODERASI PENGARUH SELF EFFICACY DAN LINGKUNGAN KERJA TERHADAP PENERAPAN TPACK PEMBELAJARAN AKUNTANSI
}

\author{
Adelina Astutik, Kardiyem \\ Universitas Negeri Semarang, Indonesia \\ adellina212@gmail.com,kardiyem@mail.unnes.ac.id
}

\begin{abstract}
Abstrak: Penelitian ini bertujuan untuk menguji pengaruh self efficacy dan lingkungan kerja terhadap penerapan TPACK pembelajaran akuntansi dengan adversity quotient sebagai variabel moderating. Penelitian ini menggunakan pendekatan kuantitatif. Populasi penelitian ini adalah guru SMK Program Keahlian Akuntansi. Teknik pengambilan sampel manggunakan sampel jenuh dengan total responden penelitian sejumlah 77 responden. Metode pengumpulan data menggunakan kuesioner. Teknik analisis data menggunakan analisis deskriptif dan analisis regresi dengan uji selisih mutlak. Hasil statistik deskriptif menunjukkan bahwa penerapan TPACK, self efficacy dan adversity quotient berada pada kategori tinggi, sedangkan lingkungan kerja berada pada kategori yang mendukung. Hasil penelitian menunjukkan self efficacy berpengaruh positif dan signifikan terhadap penerapan TPACK pembelajaran akuntansi, lingkungan kerja berpengaruh positif dan signifikan terhadap penerapan TPACK pembelajaran akuntansi. Uji selisih nilai mutlak menunjukkan adversity quotient mampu memperkuat pengaruh self efficacy terhadap penerapan TPACK pembelajaran akuntansi, adversity quotient tidak mampu memperkuat pengaruh lingkungan kerja terhadap penerapan TPACK pembelajaran akuntansi.
\end{abstract}

Kata kunci: Penerapan TPACK, Self Efficacy, Lingkungan Kerja, Adversity Quotient

\section{THE ROLE OF ADVERSITY QUOTIENT MODERATES THE EFFECT OF SELF EFFICACY AND THE WORKING ENVIRONMENT ON THE IMPLEMENTATION OF ACCOUNTING LEARNING TPACK}

\begin{abstract}
This study aims to examine the effect of self-efficacy and work environment on the application of TPACK in accounting learning with adversity quotient as avariable moderating. This study uses a quantitative approach. The population of this research is the teachers of SMK Accounting Expertise Program. The sampling technique used saturated samples with a total of 77 respondents. The data collection method used a questionnaire. The data analysis technique used descriptive analysis and regression analysis with absolute difference test. The results of descriptive statistics show that the application of TPACK, self-efficacy and adversity quotient is in the high category, while the work environment is in the supportive category. The results showed that self-efficacy had a positive and significant effect on the application of TPACK in accounting learning, the work environment had a positive and significant effect on the application of TPACK in accounting learning. The absolute value difference test shows that the adversity quotient is able to strengthen the effect of self-efficacy on the application of TPACK in accounting learning, the adversity quotient is not able to strengthen the effect of the work environment on the application of TPACK in accounting learning.
\end{abstract}

Keywords: Application of TPACK, Self-efficacy, Work Environment, Adversity Quotient

\section{PENDAHULUAN}

Abad 21 telah mengantarkan kita pada era digitalisasi yang berdampak besar pada perkembangan ilmu pengetahuan yang menjadi lebih cepat. Teknologi sebagai media untuk berkomunikasi menjadi berperan penting dalam kehidupan sehari-hari. Literasi tentang ICT (Information and Communication Technology) menjadi salah satu skill yang harus dikuasai oleh masyarakat agar dapat beradaptasi dengan perkembangan zaman yang terjadi. Salah satu pihak yang menerima dampak 
dari perkembangan ICT ini adalah guru. Seorang guru hendaknya dapat mengintegrasikan teknologi untuk mendukung strategi pembelajaran yang dilakukan. Guru harus mampu untuk menyusun perangkat pembelajaran dengan lengkap dan sistematis agar pembelajaran yang dilakukan menjadi lebih imteraktif, inspiratif, menyenangkan, menantang, dan memotivasi peserta didik untuk dapat berperan aktif dalam kegiatan pembelajaran (Hidayati et al., 2018). Faktanya hal yang terjadi sesungguhnya adalah para guru yang masih belum memahami penggunaan teknologi dalam kegiatan pembelajaran (Chen, 2010).

Saat ini pendidikan berada dimasa pengetahuan atau knowledge age. Hal ini dibuktikan dengan peningkatan pengetahuan yang cepat. Pengintegrasian teknologi dalam pendidikan sudah bukan menjadi hal yang langka. Pendidikan Indonesia ada pada teknologi. Penelitian yang dilakukan oleh Cambridge Internasional melalui Global Education Census 2018 menunjukkan bahwa siswa di Indonesia menggunakan teknologi di ruang kelas lebih banyak daripada negara lain. 40\% siswa menggunakan komputer di sekolah, 67\% siswa menggunakan ponsel pintar di sekolah. Mata pelajaran TIK (Teknologi Informasi dan Komunikasi) menjadi tidak begitu diperlukan, karena siswa sudah mengaplikasikannya dalam pembelajaran sehari-hari.

TIK pada kurikulum KTSP merupakan mata pelajaran yang dipelajari peserta didik. Hal ini berbeda dengan kurikulum 2013 yang memanfaatkan TIK sebagai media dalam pembelajarannya, bukan lagi sebatas mata pelajaran. Mata pelajaran TIK sudah dihapuskan pada kurikulum 2013. Hal ini dapat dilihat pada perbedaan struktur kurikulum antara KTSP dan Kurilulum 2013. Perbedaan tersebut dapat dilihat dari mata pelajaran yang diterapkan, yaitu KTSP menerapkan mata pelajaran KKPI (Keterampilan Komputer dan Pengelolaan Informasi), sedangkan kurikulum 2013 menerapkan mata pelajaran Simulasi Digital. Perbedaan lain dapat dilihat dari jumlah jam belajar mata pelajaran tersebut masing-masing. KKPI memiliki jumlah jam belajar 2 jam pelajaran dalam satu minggu, sedangkan Simulasi Digital memiliki jam belajar 3 jam pelajaran dalam satu minggu. Selain itu, mata pelajaran KKPI diberikan kepada peserta didik selama 6 semester, berbeda dengan Simulasi Digital yang hanya diberikan pada 2 semester awal pembelajaran.

Pengurangan jam belajar pada mata pelajaran TIK berdampak pada pengintegrasian teknologi dalam semua mata pelajaran. Permendikbud No 22 Tahun 2016 menjelaskan bahwa pemanfaatan teknologi informasi dan komunikasi digunakan untuk meningkatkan efisiensi dan efektivitas dalam pembelajaran. Hal ini berarti TIK harus menjadi alat bantu dalam proses pembelajaran Marzoan (2014). Hal ini menunjukkan bahwa semua komponen pendidikan dituntut untuk bersinergi dengan TIK.

Implementasi kurikulum 2013 Permendikbud No.81A menyebutkan bahwa pola pembelajaran harus diubah, dari pola pembelajaran satu arah (interaksi guru-peserta didik) menjadi pola pembelajaran interaktif. Peserta didik dituntut untuk lebih aktif menggali informasi terkait dengan materi yang sedang dibahas, sehingga peran guru hanya sebagai fasilitator dalam 
kegiatan pembelajaran. TIK menjadi sangat penting untuk mendukung kegiatan pembelajaran ini. Para guru juga diharuskan memiliki pengetahuan dan kemampuan dalam penguasaan TIK agar dapat mengintegrasikan TIK. Hal ini seperti yang tertera dalam Permendikbud No 22 Tahun 2016 bahwa dalam pembelajaran, penerapan teknologi informasi dan komunikasi harus diintegrasikan secara sistematis dan efektif sesuai dengan situasi dan kondisi. Penerapan pembelajaran berbasis teknologi memerlukan pengetahuan dan dasar-dasar yang sesuai berkaitan dengan materi, pedagogi, dan teknologi yang akan digunakan.

Para guru harus memiliki kompetensi pedagogik dan kompetensi profesional yang mumpuni untuk mengintegrasikan teknologi dalam pembelajaran. Kompetensi pedagogik berkaitan dengan kemampuan guru dalam mengolah pembelajaran agar peserta didik dapat memahami pelajaran yang disampaikan. Kompetensi ini terdiri dari kompetensi guru dalam menyusun rancangan pembelajaran, kompetensi pelaksanaan pembelajaran, dan kompetensi dalam penilaian proses pembelajaran. Kompetensi profesional berkaitan dengan kemampuan menguasaan materi pembelajaran secara luas dan mendalam terhadap materi pelajaran yang akan diberikan kepada peserta didik. Depdiknas (2004) menyatakan kompetensi profesional meliputi: pengembangan profesi, pemahaman wawasan, dan penguasaan bahan kajian akademik.

Fenomena yang terjadi dalam sekolah adalah masih belum optimalnya penguasaan materi dan literasi terhadap teknologi dan informasi yang dimiliki oleh guru. Hal ini dibuktikan dengan hasil uji kompetensi guru pada tahun 2019 masih belum memuaskan menurut pemerintah. Berdasarkan data yang diperoleh dari Kemendikbud menunjukkan bahwa skor UKG (Uji Kompetensi Guru) di Jawa Tengah masih belum sesuai harapan. Pemerintah berharap rata-rata hasil UKG tahun 2019 mampu mencapai angka 80.00. Hasil UKG untuk Kota Semarang sebagai ibu kota provinsi masih kurang dari 70.00. Rincian hasil UKG dapat dilihat pada tabel 1.1 berikut:

Tabel 1 Rincian Hasil UKG Kota Semarang Tahun 2019

\begin{tabular}{|c|c|c|c|}
\hline \multirow{2}{*}{ Jenjang } & \multirow{2}{*}{$\begin{array}{l}\text { Rata-rata } \\
\text { Nilai UKG }\end{array}$} & \multicolumn{2}{|c|}{ Rata-rata Nilai } \\
\hline & & Pedagogik & Profesional \\
\hline SD & 65.70 & \multirow{4}{*}{40.14} & \multirow{4}{*}{66.71} \\
\hline SMP & 68.79 & & \\
\hline SMA & 72.73 & & \\
\hline SMK & 64.51 & & \\
\hline
\end{tabular}

Hasil rata-rata UKG Kota Semarang 66.71 dan menempati urutan tertinggi ke-3 se-Jawa Tengah setelah Kota Magelang yang mendapat rata-rata UKG 67.61 dan Kota Salatiga yang mendapat rata-rata 67.48, padahal Kota Semarang merupakan Ibu Kota Provinsi Jawa Tengah yang harusnya menjadi pusat pendidikan di Jawa Tengah. Hasil UKG SMK merupakan yang paling rendah dibanding jenjang pendidikan lainnya yakni 64.51, sedangkan nilai rata-rata kompetensi pedagogi dan profesional guru di Kota Semarang masih sangat jauh dari harapan. 
Nilai rata-rata kompetensi pedagogi dan profesional guru di Kota Semarang hanya mendapat poin 40.14 dan 69.53 dari keseluruhan 100 poin masih sangat rendah.

Berdasarkan hasil uji kompetensi yang didapat, pemerintah perlu mengadakan pelatihan berkala untuk meningkatkan kompetensi guru. Menurut Supriano, 2019 (gtk.kemdikbud.go.id) pemerintah terus mengupayakan program-program yang dapat meningkatkan kualifikasi, kompetensi dan keterampilan guru agar mampu menguasai lima potensi dasar abad 21. Kelima potensi tersebut adalah kemampuan berpikir kritis, kreatif, inovatif, komunikatif, bekerja sama, dan berkolaborasi. Salah satu cara untuk menerapkan potensi dasar abad 21 adalah dengan mengimplementasikan dalam desain pembelajaran.

TPACK (Technological Pedagogical and Knowledge) merupakam salah satu desain pembelajaran. TPACK adalah sebuah kerangka kerja yang didalamnya berisi pengetahuan yang diperlukan untuk mengintegrasikan teknologi kedalam pembelajaran. Kerangka kerja ini dikembangkan oleh (Mishra \& Koehler, 2006) atas adaptasi PCK (Pedagogical Content Knowledge) oleh Shulman. Ada tiga komponen dasar dalam kerangka kerja TPACK, yaitu teknologi, pedagogi, dan konten/materi. Tujuan dari kerangka kerja TPACK ini adalah mengembangkan pengetahuan dasar seorang guru dalam mempelajari materi dan menerapkan teknologi untuk meningkatkan pemahaman dan pengalaman peserta didik serta untuk mengetahui pedagogi yang tepat untuk menyampaikan isi pembelajaran (Setyosari et al., 2016).

Penerapan TPACK dapat diukur berdasarkan tingkat: 1) TK (Technological Knowledge) yang merupakan pengetahuan guru terhadap teknologi yang mendukung kegiatan pembelajaran; 2) PK (Pedagogical Knowledge) merupakan pengetahuan yang berkaitan dengan proses dan praktik dalam penyampaian materi yang diajarkan kepada peserta didik; 3) CK (Content Knowledge) merupakan pengetahuan guru terhadap materi pelajaran yang akan disampaikan kepada peserta didik; 4) PCK (Pedagogical Content Knowledge) merupakan pengajaran yang efektif yang menerapkan pemahaman pedagogi dan materi; 5) TPK (Technological Pedagogical Knowledge) merupakan pengetahuan menggunakan teknologi yang beragam dalam mengajar; 6) TCK (Technological Content Knowledge) merujuk pada pengetahuan memberikan cara baru dalam menyampaikan materi secara spesifik; 7) dan TPCK (Technological Pedagogical Content Knowledge) yang merujuk pada pengetahuan guru dalam mengintegrasikan teknologi dalam proses pengajaran dengan konteks apapun. Diterapkannya kerangka kerja ini pada pembelajaran, diharapkan guru dapat menyampaikan konten atau materi pembelajaran kepada peserta didik menggunakan media berbasis teknologi dengan pedagogi yang sesuai.

Penelitian sebelumnya yang dilakukan terhadap TPACK adalah pada mata pelajaran IPA dan Matematika. Penelitian yang dilakukan oleh Kartal \& Afacan, (2017) meneliti TPACK IPA pada guru pra layanan ditinjau dari variabel demografi. Penelitian Wiguna et al., (2017) tentang kompetensi TPACK pada mahasiswa PPL Program Studi Pendidikan Kimia. Penelitian TPACK Matematika di India oleh Bora \& Ahmed (2018). Penelitian oleh Saputra (2019) tentang 
hubungan antara TPACK dan TISE pada guru matematika dan masih beberapa penelitian yang berkaitan dengan TPACK dan pembelajaran IPA maupun matematika.

Penerapan TPACK juga dapat dilakukan pada pembelajaran akuntansi. Pembelajaran akuntansi merupakan mata pelajaran produktif bagi peserta didik SMK dengan program keahlian akuntansi. Permendikbud No 21 Tahun 2016 menyatakan bahwa tujuan dari pembelajaran akuntansi adalah untuk membekali peseta didik dengan berbagai wawasan, serta menerapkan pengetahuan pada bidang kajian yang spesifik sesuai dengan bakat dan minatnya untuk memecahkan masalah. Mata pelajaran akuntansi memiliki tuntutan pemahaman konsep teori dan perhitungan yang kuat secara bersama (Aghni, 2018). Banyaknya materi yang perlu dipelajari dengan hitungan yang harus dikuasi dan waktu yang tersedia, menuntut guru untuk memilih media dan strategi pembelajaran yang tepat agar peserta didik dapat cepat mengingat dan memahami materi yang diberikan. Karakter pembelajaran akuntansi yang banyak hitungan seperti pada mata pelajaran matematika dan adanya teori-teori yang perlu dipahami, serta metode yang urut yang harus dilakukan sesuai dengan urutan yang sesuai seperti pada mata pelajaran IPA memungkinkan TPACK untuk dapat diintegrasikan dalam pembelajaran akuntansi, selain itu pelajaran akuntansi juga memanfaatkan TIK pada komputer dalam mata pelajaran komputer akuntansi. Sehingga sangat besar manfaatnya jika TPACK dapat diterapkan dalam pembelajaran akuntansi.

Observasi awal pada tanggal 15 sampai dengan 22 Januari 2020 yang dilakukan peneliti di beberapa SMK yang memiliki program keahlian akuntansi baik negeri maupun swasta yang ada di Kota Semarang menunjukkan bahwa sebagian besar guru SMK Akuntansi masih belum menerapkan TPACK secara maksimal. Guru akuntansi yang sudah mengetahui dan menerapkan TPACK hanya mencapai $23 \%$ dari 17 guru yang diobservasi. Penerapan TPACK pada pembelajaran akuntansi masih terbatas pada mata pelajaran komputer akuntansi. Menurut hasil observasi awal, penerapan TPACK pada pembelajaran akuntansi dapat mempermudah dalam penyampaian materi dalam mencapai tujuan pembelajaran.

Teori yang dapat digunakan untuk menjelaskan faktor-faktor yang mempengaruhi penerapan TPACK dalam pembelajaran akuntansi adalah Teori Kognitif Sosial yang dikembangkan oleh Albert Bandura, 1986 (dalam Schunk, 2012). Teori ini menonjolkan bahwa sebagian besar pembelajaran manusia terjadi dalam lingkungan sosial. Karakteristik teori kognitif sosial Albert Bandura yakni memberikan peran utama pada fungsi-fungsi pengaturan diri. Menurut Bandura (Schunk, 2012:165-166) teori ini juga menjelaskan perilaku manusia dalam interaksi timbal balik yang berkesinambungan antara faktor personal, lingkungan sosial, dan perilaku. Pembelajaran dalam teori kognitif sosial merupakan suatu aktvitas mengolah informasi tentang struktur perilaku dan peristiwa di lingkungan.

Teori kognitif sosial dalam penelitian ini sebagai wujud dari pengetahuan dan pemahaman terhadap kerangka kerja TPACK dan penerapannya dalam pembelajaran yang dilakukan di dalam 
kelas. Penerapan TPACK sebagai desain pembelajaran dalam kelas tidak terlepas dari faktorfaktor yang mempengaruhinya. Faktor orang/kognitif dalam model pembelajaran oleh Bandura (Santrock, 2012:234) memiliki peran yang paling penting, dalam hal ini adalah self efficacy. Bandura juga mengungkapkan bahwa self efficacy mempunyai pengaruh yang kuat terhadap perilaku individu. Selain itu, faktor orang/kognitif juga dapat dicerminkan melalui ketangguhan individu yang dalam penelitian ini diwakilkan oleh adversity quotient. Faktor lain yang berkaitan erat dalam teori ini adalah lingkungan sosial. Lingkungan sosial merupakan lingkungan pergaulan antar manusia, dalam penelitian ini lingkungan kerja merupakan faktor dapat mempengaruhi penerapan TPACK dalam pembelajaran.

Self efficacy merupakan keyakinan seseorang terhadap kemampuan yang dimilikinya untuk dapat melakukan sesuatu. Self efficacy guru sangat diperlukan dalam mengintegrasikan teknologi dalam pembelajaran (Stewart et al., 2013). Terdapat beberapa penelitian sebelumnya yang menggunakan variabel self efficacy dalam penelitiannya. Penelitian oleh Yang et al., (2018) yang mengatakan bahwa self efficacy berpengaruh kuat terhadap TPACK. Penelitian lain yang dilakukan oleh Cai et al., (2019) mendukung pengaruh yang positif signifikan self efficacy terhadap TPACK. Hal berbeda ditemukan oleh Yerdelen-damar et al., (2017) bahwa self efficacy tidak berpengaruh terhadap TPACK.

Faktor eksternal yang dapat mempengaruhi TPACK adalah lingkungan kerja. Zuhri (2019)memandang lingkungan kerja sebagai tempat beradanya manusia dalam melakukan segala aktivitas keseharian. Menurut Zhang \& Wang (2019) lingkungan kerja berhubungan langsung dengan penerapan TPACK walaupun hasilnya tidak signifikan. hal ini juga didukung dengan pendapat Cai et al., (2019) yang mengatakan bahwa berpengaruh secara langsung terhadap penerapan TPACK.

Adanya beberapa ketidaksesuaian hasil antara penelitian sebelumnya dan perbedaan kuat lemahnya dari variabel independen terhadap variabel dependen maka peneliti menghadirkan variabel adversity quotient sebagai variabel moderasi sebagai solusi atas perbedaan hasil penelitian terdahulu. Adversity quotient (AQ) merupakan suatu kemampuan untuk bertahan menghadapi kesulitan (Nugroho et al., 2019). Simamora (dalam Weno \& Matulessy, 2015) mengatakan bahwa adversity quotient dapat mempengaruhi kreativitas seseorang, dalam hal ini kreativitas pada guru saat mengajar peserta didiknya.

Seorang guru yang memiliki tingkat adversity quotient yang tinggi akan mampu untuk mengatasi segala kesulitan yang dihadapinya. Semakin tinggi adversity quotient yang dimiliki seorang guru dapat meningkatkan self efficacy pada guru tersebut sehingga guru mampu untuk menerapkan TPACK dalam pembelajarannya. Selain itu, lingkungan kerja merupakan faktor yang tidak dapat diabaikan dalam penerapan TPACK pada pembelajaran. Seorang guru yang berada dalam lingkungan kerja yang baik serta memiliki adversity quotient yang tinggi dapat dengan mudah menerapkan TPACK dalam pembelajarannya. 
Penelitian yang dilakukan oleh Weno \& Matulessy (2015) menemukan bahwa adversity quotient berpengaruh positif signifikan terhadap kreativitas guru dalam mengajar, dalam hal ini kreativitas yang dimaksud adalah dengan menerapkan kerangka kerja TPACK dalam pembelajara. Hasil penelitian lain oleh Nugroho et al., (2019) mengatakan bahwa adversity quotient berpengaruh terhadap kinerja guru. Menurut Darmadi (2010:60-61) kinerja guru dapat diukur dengan tanggungjawabnya dalam menjalankan amanah, profesi yang diembannya, dan tanggung jawab moral. Semua itu dapat dilihat dari loyalitasnya dalam mengajar di kelas, termasuk dalam menerapkan TPACK sebagai desain pembelajaran. Berdasarkan pemaparan tersebut peneliti berasumsi bahwa adversity quotient dapat memoderasi pengaruh self efficacy dan lingkungan kerja terhadap penerapan TPACK. Disebutkan oleh Sugiono (2004) bahwa variabel moderator adalah variabel independen kedua yang pengaruhnya dapat ditiadakan atau dinetralisir. Narbuko \& Achmadi (2016) mengatakan bahwa variabel moderasi dapat ikut mempengaruhi variabel tergantung atau variabel dependen dan memperjelas hubungan variabel independen terhadap variabel dependennya.

Pentingnya penerapan TPACK dalam pengintegrasian teknologi terhadap kegiatan pembelajaran di lingkungan sekolah, menjadikan peneliti tertarik untuk meneliti "Pengaruh Self Efficacy dan Lingkungan Kerja Terhadap Penerapan TPACK Pembelajaran Akuntansi dengan Adversity Quotient sebagai Variabel Moderating pada Guru SMK Akuntansi se-Kota Semarang". Harapannya penelitian ini dapat mengkaji lebih dalam tentang penerapan TPACK dalam pembelajaran akuntansi. Peneliti juga berharap penelitian ini dapat mengungkapkan faktorfaktor yang mempengaruhi penerapan TPACK dalam pembelajaran akuntansi.

\section{METODE}

Jenis penelitian ini adalah penelitian kuantitatif. Sumber data yang digunakan pada penelitian ini menggunakan data primer dengan teknik pengumpulan data menggunakan kuisioner. Populasi dalam penelitian ini adalah guru SMK Program Keahlian Akuntansi se-Kota Semarang dengan jumlah sekolah sebanyak 24 sekolah. Sampel yang digunakan dalam penelitian ini adalah sampel jenuh dengan total jumlah responden adalah 77 responden. Variabel yang digunakan dalam penelitian ini yaitu penerapan TPACK (Y) sebagai variabel dependen. Variabel self efficacy (X1) dan lingkungan kerja (X2) sebagai variabel independen. Variabel adversity quotient (M) sebagai variabel moderasi. Teknik analisis data yang digunakan adalah analisis statistik deskriptif dan uji selisih nilai mutlak untuk mengetahui pengaruh interaksi variabel independen terhadap variabel dependen dengan adversity quotient sebagai variabel moderasi. 


\section{HASIL DAN PEMBAHASAN}

Hasil analisis statistik deskriptif menunjukkan bahwa penerapan TPACK dalam pembelajaran akuntansi pada guru SMK Akuntansi se-Kota Semarang berada dalam kategori tinggi. Berikut tabel ringkasan hasil analisis statistik deskriptif untuk masing-masing variabel penelitian:

Tabel 2. Ringkasan Analisis Statistik Variabel

\begin{tabular}{lc}
\hline \multicolumn{1}{c}{ Variabel } & Kategori \\
\hline Penerapan TPACK & Tinggi \\
Self Efficacy & Tinggi \\
Lingkungan Kerja & Mendukung \\
Adversity Quotient & Tinggi \\
\hline
\end{tabular}

Tabel 2 menunjukkan bahwa variabel penerapan TPACK, self efficacy, dan adversity quotient berada pada kategori tinggi, sedangkan variabel lingkungan kerja berada pada kategori yang mendukung. Analisis statistik deskriptif memberikan gambaran terhadap data secara individual dengan melihat distribusi data yang diperoleh dari jawaban responden yang meliputi nilai terendah, nilai tertinggi, nilai rata-rata, dan standar deviasi yang diolah menggunakan bantuan program SPSS Statistic 25. Hasil pengolahan data dan penjelasan mengenai analisis deskriptif masing-masing variabel disajikan sebagai berikut:

Tabel 3. Statistik Deskriptif Penerapan TPACK

\begin{tabular}{cc}
\hline Statistik Deskriptif Penerapan TPACK \\
\hline N & 77 \\
Minimum & 175 \\
Maximum & 300 \\
Mean & 250.22 \\
Std. Deviation & 28.905 \\
\hline
\end{tabular}

Tabel 3 menunjukkan bahwa dari 77 responden diperoleh nilai terendah pada variabel penerapan TPACK adalah 175 dan nilai tertingginya adalah 300. Standar deviasinya sebesar 28,905 dan nilai rata-rata dari variabel penerapan TPACK sebesar 250,22, sehingga termasuk dalam kategori tinggi. Diketahui bahwa dari 77 guru SMK Akuntansi di Kota Semarang bahwa 41,56\% guru dapat menerapkan TPACK pada pembelajaran akuntansi dengan kategori sangat tinggi. 53,25\% guru dapat menerapkan TPACK pada pembelajaran akuntansi dengan kategori tinggi, dan sebanyak 5,19\% menerapkan TPACK dalam kategori cukup.

Tabel 4. Statistik Deskriptif Self Efficacy

\begin{tabular}{cc}
\hline Statistik Deskriptif Self Efficacy \\
\hline N & 77 \\
Minimum & 19 \\
Maximum & 45 \\
Mean & 36.69 \\
Std. Deviation & 5.141 \\
\hline
\end{tabular}


Tabel 4 meunjukkan bahwa dari 77 responden penelitian didapat nilai terendah variabel self efficacy 19 dan nilai tertingginya sejumlah 45. Nilai standar deviasi variabel self efficacy adalah 5,141 dengan nilai rata-rata variabel 36,69 sehingga termasuk dalam kategori tinggi. Distribusi frekuensi variabel self efficacy yaitu sebanyak 29,87\% guru akuntansi memiliki self efficacy dalam kategori sangat tinggi. Sebanyak 58,44\% guru akuntansi memiliki self efficacy dalam kategori tinggi. Sebanyak 9,09\% guru akuntansi memiliki self efficacy dalam kategori cukup, dan sebanyak 2,60\% guru akuntansi memiliki self efficacy berada dalam kategori rendah.

Tabel 5. Statistik Deskriptif Lingkungan Kerja

\begin{tabular}{cc}
\hline \multicolumn{2}{c}{ Statistik Deskriptif Lingkungan Kerja } \\
\hline $\mathrm{N}$ & 77 \\
Minimum & 24 \\
Maximum & 45 \\
Mean & 38.03 \\
Std. Deviation & 4.812 \\
\hline
\end{tabular}

Tabel 5 menunjukkan bahwa dari 77 responden penelitian, nilai minimum variabel lingkungan kerja adalah sejumlah 24 dan nilai maksimumnya sejumlah 45 . Standar deviasi variabel lingkungan kerja 4,812 dan nilai rata-ratanya 38,03 sehingga termasuk dalam kategori yang mendukung. Distribusi frekuensi variabel lingkungan kerja yaitu sebanyak 36,37\% guru akuntansi bekerja dalam lingkungan yang sangat mendukung. Sebanyak 55,84\% guru akuntansi bekerja pada lingkungan yang mendukung, dan sebanyak 7,79\% guru akuntansi bekerja pada lingkungan yang kukup mendukung.

Tabel 6. Statistik Deskriptif Adversity Quotient

\begin{tabular}{cc}
\hline Statistik Deskriptif & Adversity \\
\hline Quotient \\
Minimum & 77 \\
Maximum & 45 \\
Mean & 75 \\
Std. Deviation & 61.91 \\
\end{tabular}

Tabel 6 menunjukkan bahwa dari 77 responden penelitian diperoleh nilai terendah pada variabel adversity quotient yaitu 45 dan nilai tertingginya 75 . Standar deviasi variabel adversity quotient adalah 7,297 dan nilai rata-ratanya adalah 61,91 sehingga termasuk dalam kategori tinggi. Distribusi frekuensi variabel adversity quotient yakni sebanyak 36,36\% guru akuntansi di Kota Semarang memiliki adversity quotient berada dalam kategori sangat tinggi. Sebanyak 59,74\% guru SMK Akuntansi meliliki adversity quotient berada pada kategori tinggi, dan sebanyak 3,90\% guru akuntansi memiliki adversity quotient yang berada pada kategori cukup. 
Analisis yang digunakan berikutnya adalah uji selisih nilai mutlak. Sebelum dilakukan uji tersebut terlebih dahulu dilakukan uji prasyarat dan uji asumsi klasik. Uji prasyarat terdiri dari uji normalitas dan uji linearitas. Sedangkan uji asumsi klasik terdiri dari uji multikolinearitas dan uji heteroskedastisitas. Uji normalitas menggunakan nilai signifikansi kolmogorov-smirnov dengan penerapan TPACK sebagai variabel dependen adalah $0,383>0,05$ sehingga data residual berdistribusi normal. Uji berikutnya adalah uji linearitas yang menggunakan uji Durbin-Watson ( $D$ $W$ ) dengan ketentuan nilai D-W > d1. Hasil uji linearitas dapat dilihat pada kolom berikut:

Tabel 7. Hasil Uji Linearitas

\begin{tabular}{lllll}
\hline \multicolumn{5}{c}{ Model Summary } \\
\hline $\mathrm{R}$ & $\mathrm{R}$ & Adjusted & Std. & D-W \\
& Square & R Square & Error & \\
$.885^{\mathrm{a}}$ & .783 & .774 & 13.751 & 2.226 \\
\hline
\end{tabular}

Tabel 7 menunjukkan bahwa nilai D-W adalah sebesar 2,226. Nilai tersebut lebih besar daripada nilai dl dengan $\mathrm{n}=77$ dan $\mathrm{k}=3$, yaitu $\mathrm{dl}=1,57710$. Hasil tersebut menunjukkan bahwa model persamaan yang digunakan memiliki hubungan yang linear. Uji Multikolinearitas bertujuan untuk menguji apakah model regresi ditemukan adanya korelasi antar variabel bebas (independen). Cara untuk mendeteksi ada tidaknya multikolinearitas di dalam model regresi adalah dengan melihat nilai Tolerance dan VIF. Apabila nilai Tolerance $\geq 0,10$ dan VIF $\leq 10$, maka dapat disimpulkan bahwa tidak ada multikolinearitas. Hasil uji multikolinearitas dapat dilihat pada tabel 8 berikut:

Tabel 8. Hasil Uji Multikolinearitas

\begin{tabular}{ccc}
\hline \multicolumn{3}{c}{ Koefisien } \\
\hline Model & Tolerance & VIF \\
SE & .476 & 2.099 \\
LK & .438 & 2.282 \\
AQ & .866 & 1.155 \\
\hline
\end{tabular}

Tabel 8 menunjukkan bahwa masing masing variabel, yakni self efficacy (SE), lingkungan kerja (LK) dan adversity quotient (AQ) memiliki nilai tolerance $>0,10$ dengan nilai $\mathrm{VIF}<10$, sehingga kesimpulannya adalah masing-masing variabel independen yang digunakan tidak mengandung multikolinearitas. Uji asumsi klasik berikutnya yaitu uji heteroskedastisitas. Pengujian gejala heteroskedastisitas dalam penelitian ini dilakukan menggunakan uji koefisien korelasi Rank Spearman dengan melihat nilai signifikansi. Hasil pengujian heteroskedastisitas dapat dilihat pada Tabel 9. berikut: 
Tabel 9. Hasil Uji Heteroskedastisitas

\begin{tabular}{cl}
\hline Model & Sig \\
\hline SE & .617 \\
LK & .932 \\
AQ & .913 \\
\hline
\end{tabular}

Hasil uji heteroskedastisitas pada Tabel 9 menunjukkan bahwa variabel self efficacy $(0,617>$ $0,05)$, lingkungan kerja $(0,932>0,05)$, dan adversity quotient $(0,913>0,05)$ mempunyai nilai signifikansi $>0,05$ sehingga dapat disimpulkan bahwa pada model regresi tidak terdapat heteroskedastisitas. Uji selanjutnya yaitu uji selisih nilai mutlak yang dilakukan untuk mengetahui pengaruh interaksi antara variabel moderasi dengan variabel independen terhadap variabel dependen. Adapun hasil uji selisih nilai mutlak per variabel adalah sebagai berikut:

Tabel 10. Hasil Uji Selisih Nilai Mutlak

\begin{tabular}{lcc}
\hline \multicolumn{1}{c}{ Hipotesis } & Koefisien & Sig \\
\hline Constant & 247.194 & .000 \\
Zscore(SE) & 19.792 & .000 \\
Zscore(LK) & 8.299 & .000 \\
SE_AQ & 5.436 & .035 \\
LK_AQ & -2.096 & .457 \\
\hline
\end{tabular}

Hasil uji selisih nilai mutlak pada Tabel 10 menunjukkan nilai konstanta sebesar 247,194. Self efficacy memiliki koefisien regresi sebesar 19,792. Lingkungan kerja memiliki koefisien 8,299. Koefisien regresi selisih nilai mutlak variabel self efficacy dengan adversity quotient sebesar 5.436. koefisien regresi selisih nilai mutlak variabel lingkungan kerja dengan adversity quotient sebesar 2,096. Model regresi yang terbentuk adalah sebagai berikut:

$\mathrm{PT}=247,194+$ 19,792SE + 8,299LK + 5.436SE_AQ - 2,096LK_AQ + e

Persamaan regresi moderasi di atas dapat diartikan bahwa Konstanta sebesar 247,194 memiliki arti bahwa ketika variabel bebas bernilai nol (0), maka penerapan TPACK pada guru akuntansi se-Kota Semarang bernilai 247,194. Koefisien regresi variabel self efficacy sebesar 19,792 berarti bahwa jika self efficacy mengalami peningkatan sebesar satu satuan, maka penerapan TPACK pada pembelajaran akuntansi mengalami peningkatan sebesar 19,792 dengan asumsi bahwa variabel independen lainnya bernilai tetap. Koefisien regresi variabel lingkungan kerja sebesar 8,299 berarti bahwa jika lingkungan kerja mengalami peningkatan sebesar satu satuan, maka penerapan TPACK pada pembelajaran akuntansi mengalami peningkatan sebesar 8,299 dengan asumsi bahwa variabel independen lainnya bernilai tetap.

Koefisien regresi selisih mutlak self efficacy dan adversity quotient sebesar 5,436. Hal ini berarti jika self efficacy dengan adversity quotent mengalami peningkatan sebesar satu satuan, maka penerapan TPACK pada pembelajaran akuntansi mengalami peningkatan sebesar 5,436. Koefisien bernilai positif berarti adanya interaksi self efficacy dan adversity quotient mampu memperkuat pengaruh self efficacy terhadap penerapan TPACK pada pembelajaran akuntansi. 
Koefisien regresi selisih mutlak lingkungan kerja dan adversity quotient sebesar -2,096. Hal ini berarti jika lingkungan kerja dengan adversity quotient mengalami peningkatan sebesar satu satuan, maka penerapan TPACK pada pembelajaran akuntansi mengalami penurunan sebesar 2,096. Koefisien bernilai negatif berarti adanya interaksi lingkungan kerja dan adversity quotient tidak mampu memperkuat pengaruh lingkungan kerja terhadap penerapan TPACK pada pembelajaran akuntansi.

Peneliti juga melakukan uji koefisien determinasi secara parsial. Uji koefisien determinasi parsial $\left(\mathrm{r}^{2}\right)$ dilakukan untuk mengetahui kontribusi masing-masing variabel independen dalam menjelaskan variabel dependen. Berikut Tabel hasil uji koefisien determinasi parsial:

Tabel 11. Uji Koefisien Determinasi Parsial $\left(\mathrm{r}^{2}\right)$

\begin{tabular}{lccc}
\hline \multicolumn{1}{c}{ Model } & Zero-order & Partial & Part \\
\hline Zscore(SE) & .854 & .726 & .476 \\
Zscore(LK) & .755 & .412 & .204 \\
SE_AQ & -.060 & .245 & .114 \\
LK_AQ & .085 & -.088 & -.040 \\
\hline
\end{tabular}

Berdasarkan Tabel 11. dapat diketahui bahwa variabel self efficacy memiliki nilai correlation partial sebesar 0,726. Nilai tersebut kemudian dikuadratkan $(0,7262)=0,5270$ dan dipersentasekan $(0,5270 \times 100 \%)=52,70 \%$. Hal ini berarti secara parsial, variabel self efficacy mempengaruhi penerapan TPACK pada pembelajaran akuntansi sebesar 52,70\%. Variabel lingkungan kerja memiliki nilai correlation partial sebesar 0,412. Nilai tersebut dikuadratkan $(0,4122)=0,1697$ kemudian dipersentasekan $(0,1697 \times 100 \%)=16.97 \%$. Secara parsial variabel lingkungan kerja berpengaruh terhadap penerapan TPACK pembelajaran akuntansi sebesar $16,97 \%$. Selisih mutlak variabel self efficacy dan adversity quotient memiliki nilai correlation partial sebesar 0,245. Nilai tersebut kemudian dikuadratkan $(0,2452)=0,0600$ dan dipersentasekan $(0,0600 \times 100 \%)=6 \%$. Secara parsial interaksi antara variabel self efficacy dan adversity quotient mempengaruhi penerapan TPACK pada pembelajaran akuntansi sebesar 6\%.

Hasil correlation partial interaksi antara variabel lingkungan kerja dan adversity quotient adalah sebesar $-0,088$. Nilai tersebut kemudian dikuadratkan $(-860,0882)=0,0077$ dan dipersentasekan $(0,0077 \times 100 \%)=0,77 \%$. Secara parsial, interaksi antara variabel lingkungan kerja dan adversity quotient berpengaruh terhadap penerapan TPACK pada pembelajaran akuntansi sebesar $0,77 \%$

\section{Pengaruh Self Efficacy terhadap Penerapan TPACK}

Hipotesis $\mathrm{Ha}_{1}$ yang menyatakan bahwa "Terdapat pengaruh yang positif dan signifikan self efficacy terhadap penerapan TPACK dalam pembelajaran akuntansi" dinyatakan diterima. Hal ini dibuktikan dengan uji signifikansi parsial (uji t) yang menghasilkan nilai signifikansi $0,000<0,05$ dari nilai koefisien regresi sebesar 19,729. Berdasarkan nilai regresi tersebut berarti bahwa setiap 
peningkatan variabel self efficacy sebesar satu satuan maka akan meningkatkan penerapan TPACK pada pembelajaran akuntansi sebesar 19,729. Kontribusi secara parsial variabel self efficacy terhadap penerapan TPACK pada pembelajaran akuntansi adalah sebesar 52,70\%.

Hasil analisis deskriptif variabel self efficacy menunjukkan bahwa rata-rata tingkat self efficacy yang dimiliki guru akuntansi di Kota Semarang berada dalam kategori tinggi. Indikator yang digunakan untuk mengukur variabel self efficacy adalah level, strength dan generality. Indikator level, strength, dan generality masing-masing berada dalam kategori tinggi. Hasil analisis statistik deskriptif juga menunjukkan bahwa variabel penerapan TPACK berada dalam kategori tinggi. Sehingga dapat disimpulkan bahawa semakin tinggi tingkat self efficacy yang dimiliki oleh guru akuntansi di Kota Semarang maka akan menghasilkan penerapan TPACK pada pembelajaran akuntansi yang semakin tinggi juga.

Jika dilihat dari masing-masing indikatornya yang berada dalam kategori tinggi, hal ini memungkinkan guru akuntansi dapat menerapkan TPACK pada pembelajarannya. Seorang guru akuntansi yang memiliki kesadaran terhadap kemampuan yang dimiliki (level) berada pada kategori tinggi akan dapat memilah dan menerapkan teknologi pada pembelajaran akuntansi dengan tepat karena guru tersebut akan berusaha untuk melaksanakan tugas yang mampu ia kerjakan. Ketika seorang guru tersebut memiliki strength yang tingga maka ia akan memiliki keyakinan terhadap kemampuan yang dimilikinya sehingga akan mendorongnya untuk menerapkan TPACK dalam pembelajaran. Level dan strength yang tinggi dibarengi dengan generality yang tinggi akan membuat guru akuntansi dapat menerapkan TPACK pada pembelajaran akuntansi dengan mudah karena ia mengetahui kelebihan dan kelemahannya sehingga dapat mengantisipasi segala kesulitan yang mungkin akan dihadapinya.

Penelitian ini juga berhasil mengonfirmasi teori kognitif sosial Bandura, 1986 (dalam Schunk, 2012) yang menyatakan bahwa self efficacy memiliki pengaruh yang kuat terhadap perilaku pada diri manusia. Self efficacy ini termasuk dalam faktor kognitif/orang. Sedangkan faktor perilaku yang dimaksud dalam hal ini adalah penerapan TPACK pada pembelajaran akuntansi yang dilakukan oleh guru akuntansi. Sehingga dengan self efficacy yang tinggi seorang guru akuntansi akan mampu untuk menerapkan TPACK pada pembelajaran akuntansi yang dilakukan. Penelitian ini juga sejalan dengan penelitian yang dilakukan oleh Yang et al (2018) yang menyatakan bahwa self efficacy berpengaruh sangat kuat terhadap TPACK yang dilakukan pada guru matematika di China.

\section{Pengaruh Lingkungan Kerja Terhadap Penerapan TPACK}

Hasil uji hipotesis menunjukkan bahwa $\mathrm{Ha}_{2}$ yang menyatakan "Terdapat pengaruh yang positif dan signifikan lingkungan kerja terhadap penerapan TPACK dalam pembelajaran akuntansi" dinyatakan diterima. Hal ini berdasarkan hasil uji signifikansi parsial (uji t) pada variabel lingkungan kerja dengan signifikansi $0,000<0,05$ dan nilai koefisien regresi sebesar 
8,299. Nilai koefisien regresi tersebut berarti bahwa setiap kenaikan satu satuan variabel lingkungan kerja maka akan menyebabkan kenaikan sebesar 8,299 pada variabel penerapan TPACK. adapun kontribusi parsia variabel lingkungan kerja terhadap penerapan TPACK pada pembelajaran akuntansi adalah sebesar 16,97\%.

Hasil analisis deskriptif variabel lingkungan kerja juga menunjukkan ratarata tingkat lingkungan kerja guru akuntansi di Kota Semarang berada dalam kategori mendukung. Lingkungan kerja dalam penelitian ini terdiri dari tiga indikator yaitu hubungan antar karyawan, suasana kerja, dan fasilitas-fasilitas kerja. Indikator hubungan antar karyawan berada pada kategori mendukung, begitu juga dengan indikator suasana kerja dan fasilitas-fasilitas kerja berada pada kategori mendukung. Hasil analisis deskriptif juga menunjukkan bahwa penerapan TPACK berada pada kategori tinggi. Sehingga dapat disimpulkan bahwa semakin mendukung lingkungan kerja tempat guru akuntansi bekerja maka akan semakin mempengaruhi tingkat penerapan TPACK pada pembelajaran akuntansi.

Berdasarkan indikator yang digunakan, variabel lingkungan kerja berada pada kategori mendukung. Masing-masing indikator juga berada pada kategori mendukung, sehingga seorang guru akuntansi akan dapat menerapkan TPACK 89 pada pembelajaran akuntansi. Seorang guru akuntansi yang memiliki hubungan kerja yang baik dengan guru lain maka akan mendorongnya untuk mampu menerapkan TPACK dengan bantuan dari guru lain. Selain itu, ketika suasana kerja tempat guru akuntansi bekerja mendukung dan fasilitas yang tersedia di tempat kerja juga terpenuhi maka akan memudahkan bagi guru untuk dapat menerapkan TPACK dalam pembelajaran akuntansi.

Penelitian ini dilakukan untuk mengonfirmasi teori kognitif sosial Bandura,1986 (dalam Schunk, 2012) bahwa lingkungan dapat mempengaruhi perilaku. Pada penelitian ini lingkungan yang dimaksud adalah lingkungan kerja. Lingkungan kerja yang baik akan mendorong kemampuan seorang guru untuk dapat menerapkan TPACK pada pembelajaran akuntansi. Penelitian ini juga mendukung penelitian Zhang \& Wang (2019) yang menyatakan bahwa lingkungan kerja berpengaruh langsung terhadap penerapan TPACK.

\section{Adversity Quotient Memperkuat Pengaruh Self Efficacy terhadap Penerapan TPACK}

$\mathrm{Ha}_{3}$ dalam penelitian ini adalah "Adversity quotient memperkuat pengaruh self efficacy terhadap penerapan TPACK pada pembelajaran akuntansi" dinyatakan diterima. Hal ini dibuktikan dengan hasil regresi uji t dengan nilai signifikansinya $0,035<0,05$ dan nilai koefisien regresinya sebesar 5,436. Nilai koefisien regresi bernilai positif sehingga berarti bahwa adversity quotient memperkuat pengaruh self efficacy terhadap penerapan TPACK pada pembelajaran akuntansi. Semakin tinggi tingkat adversity quotient guru akuntansi maka akan semakin meningkatkan pengaruh self efficacy terhadap penerapan TPACK pada pembelajaran akuntansi 
Hasil analisis deskriptif menunjukkan bahwa rata-rata tingkat adversity quotient guru akuntansi di Kota Semarang berada pada kategori tinggi, begitu juga dengan variabel self efficacy. Hal ini berarti bahwa guru akuntansi di Kota Semarang memiliki tingkat adversity quotient yang tinggi sehingga mendukung untuk memperkuat pengaruh self efficacy terhadap penerapan TPACK pada pembelajaran akuntansi.

Adversity quotient pada penelitian ini diukur menggunakan indikator control, origin \&ownership, reach, dan endurance. Semua indikator berada pada ketegori tinggi. Seorang guru akuntansi yang memiliki control yang tinggi maka dia dapat mengendalikan dirinya agar tidak mendapatkan kesulitan dalam menerapkan TPACK. Guru akuntansi yang memiliki origin \&ownership pada kategori tinggi juga akan mampu menganalisis sumber kesulitan yang dihadapi dalam menerapkan TPACK pada pembelajaran sehingga akan mampu menangani kesulitan tersebut. Seorang guru akuntansi dengan reach yang tinggi akan mampu untuk menanalisis sejauh mana kesulitan yang menghambat akan mempengaruhi dirinya dalam menerapkan TPACK pada pembelajaran akuntansi. Guru akuntansi yang memiliki endurance pada kategori tinggi akan mampu untuk menganalisis berapa lama kesulitan yang datang akan berlangsung dalam penerapan TPACK pada pembelajaran akuntansi sehingga akan menemukan cara untuk dapat mengatasinya. Adversity quotient sebagai variabel moderasi mampu memoderasi hubungan antara self efficacy terhadap penerapan TPACK pada pembelajaran akuntansi, sehingga adversity quotient ini termasuk jenis moderasi semu atau quasi moderator.

\section{Adversity Quotient Memperkuat Pengaruh Lingkungan Kerja terhadap Penerapan TPACK}

Berdasarkan hasil penelitian, $\mathrm{Ha}_{4}$ pada penelitian ini yang menyatakan bahwa "Adversity quotient memperkuat pengaruh lingkungan kerja terhadap penerapan TPACK dalam pembelajaran akuntansi" dinyatakan ditolak. Hal ini ditunjukkan oleh hasil uji t yang menunjukkan nilai signifikansi 0,457>0,05. Koefisien nilai regresi bernilai -2,096 yang berarti bahwa adversity quotient tidak mampu memperkuat pengaruh lingkungan kerja terhadap penerapan TPACK pada pembelajaran akuntansi.

Hasil uji analisis deskriptif menyatakan bahwa rata-rata tingkan adversity quotient guru akuntansi di Kota Semarang berada pada kategori tinggi, begitu juga dengan variabel lingkungan kerja yang berada pada kategori mendukung. Berdasarkan teori kognitif sosial Bandura, 1986 (dalam Schunk, 2012)seharusnya adversity quotient dapat memperkuat pengaruh lingkungan kerja terhadap penerapan TPACK pada pembelajaran akuntansi. Lingkungan kerja merupakan faktor lingkungan yang dapat mempengaruhi perilaku guru untuk dapat menerapkan TPACK pada pembelajaran akuntansi. Adversity quotient termasuk faktor orang/kognitif berupa kemampuan untuk mengendalikan diri ketika menghadapi kesulitan sehingga seharusnya mampu memperkuat pengaruh lingkungan terhadap perilaku. 
Adversity quotient diukur menggunakan indikator control, origin \& ownership, reach, dan endurance. Masing-masing indikator berada pada kategori tinggi. Namun interaksi antara variabel adversity quotient dan variabel lingkungan kerja tidak membuat pengaruh lingkungan kerja terhadap penerapan TPACK semakin tinggi. Hal ini disebabkan karena adversity quotient merupakan kemampuan yang dimiliki oleh seorang individu untuk bertahan dalam kesulitan serta mengubah kesulitan tersebut menjadi peluang, sehingga guru akuntansi dengan adversity quotient yang tinggi tidak melihat lingkungan kerja merupakan sebuah hambatan yang sulit. Selain itu, lingkungan kerja juga berada dalam kategori yang mendukung sehingga memungkinkan guru untuk menerapkan TPACK pada pembelajaran akuntansi tanpa hambatan yang berarti.

\section{SIMPULAN}

Simpulan dari penelitian ini adalah terdapat pengaruh yang positif dan signifikan self efficacy terhadap penerapan TPACK dalam pembelajaran akuntansi pada guru SMK akuntansi se Kota Semarang. Terdapat pengaruh yang positif dan signifikan lingkungan kerja terhadap penerapan TPACK dalam pembelajaran akuntansi pada guru SMK akuntansi se Kota Semarang. Adversity quotient mampu memperkuat pengaruh self efficacy terhadap penerapan TPACK dalam pembelajaran akuntansi pada guru SMK akuntansi se Kota Semarang. Adversity quotient tidak mampu memperkuat pengaruh lingkungan kerja terhadap penerapan TPACK dalam pembelajaran akuntansi pada guru SMK akuntansi se Kota Semarang.

\section{DAFTAR PUSTAKA}

Aghni, R. I. (2018). FUNGSI DAN JENIS MEDIA PEMBELAJARAN AKUNTANSI. Jurnal Pendidikan Akuntansi Indonesia, XVI(1), 98-107.

Bora, A., \& Ahmed, S. (2018). an Investigation on Mathematics Teachers ' Technological Pedagogical Content Knowledge ( Tpack) in Secondary School Setting in Assam. International Journal of Technical Innovation in Modern Engineering \& Science (IJTIMES), 5(5), $530-536$.

Cai, W., Wen, X., Cai, K., \& Lv, Z. (2019). Measure and Improvement Path of TPACK Context of Professional Teachers of Civil Engineering in Higher Education. 65, 276-291. https://doi.org/https://doi.org/10.33788/rcis.65.17

Chen, R. J. (2010). Investigating models for preservice teachers' use of technology to support student-centered learning. Computers and Education, 55(1), 32-42. https://doi.org/10.1016/j.compedu.2009.11.015

Damar, S. Y., Boz, Y., \& Gunbatar, S. A. (2017). Mediated Effects of Technology Competencies and Experiences on Relations among Attitudes Towards Technology Use, Technology Ownership, and Self Efficacy about Technological Pedagogical Content Knowledge. Sci Educ Technol. https://doi.org/10.1007/s10956-017-9687-z 
Darmadi, H. (2010). Kemampuan Dasar Mengajar. Alfabeta.

Depdiknas. (2004). Depdiknas Tentang Kompetensi Guru (Issue 9). Citra Umbara.

Hidayati, N., Setyosari, P., \& Soepriyanto, Y. (2018). Technological Pedagogical Content Knowledge (TPACK) Guru Soshum Setingkat SMA. JKTP, 1(4), 291-298.

Kartal, T., \& Afacan, O. (2017). Examining Turkish Pre- service Science Teachers' Technological Pedagogical Content Knowledge ( TPACK ) Based on Demographic Variables. TURKISH SCIENCE EDUCATION, 14(1). https://doi.org/10.12973/tused.10187a

Marzoan. (2014). PERAN TEKNOLOGI INFORMASI DAN KOMUNIKASI UNTUK MENINGKATKAN KUALITAS PEMBELAJARAN DALAM PERSPEKTIF KURIKULUM 2013 Marzoan STKIP Hamzar Lombok Utara Lokok Aur Desa Karang Bajo Kec . Bayan Kab . Lombok Utara 83354 ROLE OF INFORMATION AND COMMUNICATION TECHN. Jurnal Inovasi Dan Teknologi Pembelajaran, 1(1), 81-89.

Mishra, P., \& Koehler, M. J. (2006). Technological Pedagogical Content Knowledge: A Framework for Teacher Knowledge. 108(6), 1017-1054.

Narbuko, C., \& Achmadi, A. (2016). Metodologi Penelitian. Bumi Aksara.

Nugroho, A. M., Wardono, Waluyo, S. B., \& Cahyono, A. N. (2019). Kemampuan Berpikir Kreatif ditinjau dari Adversity Quotient pada Pembelajaran TPACK. PRISMA, Prosiding Seminar Nasional Matematika, 2(1), 40-45.

Santrock, J. W. (2009). PSIKOLOGI PENDIDIKAN. In R. Oktafiani (Ed.), Salemba Humanika (3rd ed.). Salemba Humanika.

Saputra, D. D. (2019). HUBUNGAN ANTARA TECHNOLOGICAL PEDAGOGICAL CONTENT KNOWLEDGE ( TPACK ) DENGAN TECHNOLOGY INTEGRATION SELF EFFICACY ( TISE) GURU MATEMATIKA.

Schunk, D. H. (2012). LEARNING THEORIES An Educational Perspective. In E. Setyowati (Ed.), Pustaka Pelajar (keenam). Pustaka Pelajar.

Setyosari, P., Kamdi, W., \& Ulfa, S. (2016). DEVELOPING DIGITAL CONTENT OF TEACHER SYSTEM LEARNING MODA AT NETWORKING (DARING) USING LEARNING MANAGEMENT SYSTEM (LSM) MOODLE AND TECHNOLOGICAL PEDAGOGICAL CONTENT AND KNOWLEDGE (TPACK) FRAMEWORK. Proceedings of International Reasearch Clinic \& Scientific Publications of Educational Technology, 279-293.

Stewart, J., Antonenko, P. D., Robinson, J. S., \& Mwavita, M. (2013). Intrapersonal Factors Affecting Technological Pedagogical Content Knowledge of Agricultural Education Teachers. Journal of Agricultural Education, 54(3), 157-170. https://doi.org/10.5032/jae.2013.03157

Sugiono. (2004). Konsep, Identifikasi, Alat Analisis Dan Masalah Penggunaan Variabel Moderator. Jurnal Studi Manajemen \& Organisasi, 1(2), 61-70. 
https://doi.org/10.14710/jsmo.v1i2.4175

Weno, J. H., \& Matulessy, A. (2015). Adversity Quotient, Komitmen Kerja dan Kreativitas Guru SD Kelas satu. Pesona, Jurnal Psikologi Indonesia, 4(02), 162-174.

Wiguna, R., Fitri, Z., \& Erlindawati. (2017). Kompetensi Technological Pedagogical And Content Knowledge Pada Mahasiswa Program Praktik Lapangan Program Studi Pendidikan Kimia Keywords : Technological Pedagogical and Content Knowledge , Internship students Abstrak Technological Pedagogical and Conten. Jurnalilmiah Mahasiswa Pendidikan Kimia, 2(2), 117 126.

Yang, X., Ji, M., Zhang, J., Zhang, J., \& Zhang, H. (2018). A Study on the Influencing Factors of Mathematics Pre-service Teacher' s. 2018 International Joint Conference on Information, Media and Engineering (ICIME), 168-171. https://doi.org/10.1109/ICIME.2018.00042

Zhang, Y., \& Wang, Y. (2019). Empirical Study on the Influencing Factors of ICT-TPCK in Higher Vocational Teachers Empirical Study on the Influencing Factors of ICT-TPCK in Higher Vocational Teachers.

Zuhri, D. (2019). Lingkungan Kerja dan Motivasi Kerja Guru di Kabupaten Kampar: Analisis Kuantitatif. Jurnal Ilmiah Untuk Peningkatan Mutu Penddikan, 6(1). 